\title{
KONSEP PENGAWASAN, KERANGKA AUDIT SYARIAH, DAN TATA KELOLA LEMBAGA KEUANGAN SYARIAH
}

\author{
Minarni \\ Mahasiswa Magister Studi Islam, Program Pascasarjana, Fakultas Ilmu Agama Islam, Universitas \\ Islam Indonesia \\ e-mail:minarni.uii@gmail.com
}

\begin{abstract}
Abstrak
Artikel ini menganalisis beberapa konsep penting, yaitu pengawasan pada lembaga keuangan syariah, kerangka audit syariah, dan tata kelola perusahaan bagi lembaga keuangan syariah. Kajian dilakukan dengan studi pustaka mengacu pada kajian terdahulu terkait topik yang relevan. Hasilnya menunjukkan bahwa pengawasan pada bank syariah, audit syariah dan tata kelola perusahaan tidak berarti dapat menggantikan tugas manajemen bank dan tidak menjamin bank bebas dari krisis, kerugian maupun kebangkrutan. Untuk itu Bank Indonesia hendaknya mendukung kegiatan pengawasan perbankan Syariah yang melibatkan DSN dan DPS. Audit syariah juga hendaknya dijalankan sesuai standar audit AAOFI.Sedangkan tata kelola perusahaan hendaklah dimaksimalkan agar memenuhi tanggung jawab sosial perusahaan.
\end{abstract}

Kata Kunci: pengawasan lembaga keuangan syariah, audit syariah, tata kelola perusahaan yang baik

\begin{abstract}
This article analyzedsome important concepts such us supervisory, sharia auditing, and good corporate governance for Islamic finance institutions. Analysis was conducted using library research based on previous relevan studies. The results suggested that the existence of Islamic finance institutions supervisory, sharia auditing, and good corporate governancecould not replace bank management functions as well as was not a guarantee of lack of bank crisis, failure even bancruptcy. Therefore, it urguedBank of Indonesia to support Islamic finance institutions supervisory which involved DSN (National Sharia Board) and DPS (Sharia Supervisory Board). Haria auditing should also be endorsed as AAOFI standar while corporate governanceshould be optimized to fulfill corporate social responsibility.
\end{abstract}

Keywords: Islamic finance institutions supervisory, sharia auditing, good corporate governance

\section{PENDAHULUAN}

Bank Syariah menjadi salah satu bagian dari Lembaga Keuangan Syariah (LKS) yang memiliki karakteristik berbeda dengan entitas konvensional. Perbedaan karakter tersebut mempengaruhi bentuk dan standar dalam kegiatan pengawasan lembaga bank syariah termasukpelaksanaan auditnya. Pengawasan bank syariah yang berada dalam 
otoritas Bank Indonesia $(\mathrm{BI})^{1}$ dan Dewan Syariah Nasional (DSN)dilakukan dalam rangka menjaga kepatuhan terhadap prinsip-prinsip dan aturan syariah dalam operasional kegiatannya dan pelaporannya sesuai konsep perbankan syariah serta sesuai prinsip akuntansi bertema umum. ${ }^{2}$ Dalam hal ini,Dewan Pengawas Syariah (DPS) memiliki peran yang utama dalam pengendalian dalam aspek syariah dan auditor memiliki peran utama dalam menguji (examination) penyajian laporan keuangan yang fair. Adapun standar audit yang berlaku pada LKS termasuk bank Syariah adalah standar audit yang dikeluarkan dan disahkan oleh AAOIFI (Accounting and Auditing Organization for Islamic Financial Institutions) yang berada di Manama, Bahrain.

LKS khususnya bank syariahbergerak di sektor keuangan (finance)yang umumnya memiliki risiko yang tinggi dalam pengelolaan bisnisnya. Oleh karena itu, disamping adanya pengawasan dan audit syariah,diperlukan elemen lain yang mendukung kesuksesan perbankan syariah yaitu good corporate governance(tata kelola perusahaan yang baik).Tujuan corporate governance secara umum adalah untuk mewujudkan keadilan bagi seluruh pihak yang berkepentingan terhadap perusahaan (stakeholder).

Dalam mewujudkan pengawasan bank syariah yang efektif dan efisien maka BI, DSN, dan DPS harus saling bekerja sama dalam mengemban tugasnya dengan sebaikbaiknya. Dan untuk mewujudkan good corporate governance seluruh pihak baik dewan direksi, manajemen bank, auditor, stakeholder dan pihak lainnya harus saling memberikan informasi yang benar guna mendukung pertanggungjawaban masingmasing pihak kepada otoritas yang sesuai dan kepada masyarakat yang bermitra dengan Bank Syariah. Seluruh upaya tersebut memerlukan dukungan dari pemerintah yang diwakili oleh BI yang telah diberikan kepercayaan dalam membuat kebijakan berupa regulasi-regulasi yang terarah, efisien dan efektif.

Artikel ini dimaksudkan untuk menganalisa beberapa konsep penting, yaitu pengawasan pada lembaga keuangan syariah, kerangka audit syariah, dan tata kelola perusahaan bagi lembaga keuangan syariahsecara umum. Kajian dilakukan dengan studi pustaka mengacu pada kajian terdahulu dan diakhiri dengan analisis kritis.

\section{KONSEP PENGAWASAN LEMBAGA KEUANGAN SYARIAH}

Konsep pengawasan terhadap praktek keuangan yang dilakukan pada lembaga keuangan syariahmemiliki sejumlah landasan, yaitu landasan syariahdan landasan hukum positif yang berlaku di Indonesia. Landasan syariahyang biasa diacu misalnya adalah pemahaman terhadap QS. Al-Ashr [103] ayat 1-3 yang terjemahannya adalah

${ }^{1}$ Sesuai dengan UU No. 21 tahun 2011 tentang Otoritas Jasa Keuangan (OJK), kewenangan mengawasi perbankan, termasuk bank syariah, secara bertahap akan dilakukan oleh OJK.

${ }^{2}$ Dalam konteks internasional memang terdapat sejumlah perbedaan dalam penyajian laporan sebagai konsekuensi perbedaan pendekatan terhadap pengaturan keuangan Syariah. Lihat Rifaat Ahmed Abdel Karim (2001), 'International Accounting Harmonisation, Banking Regulation, and Islamic Bank', The International Journal of Accounting, Volume 36, Issue 2, May 2001, pp. 169-193. 
"Demi masa.Sesungguhnya manusia itu benar-benar dalam kerugian, kecuali orang-orang yang beriman dan mengerjakan amal saleh dan nasehat menasehati supaya mentaati kebenaran dan nasehat menasehati supaya menetapi kesabaran." Pemahaman dan pemaknaan secara luas terhadap ayat-ayat dalam surat ini menunjukkan bahwa manusia pada umumnya akan mengalami kerugian kecuali jika mampu saling menasehati atau saling mengontrol.

Adapun landasan hukum positif antara lain dapat diacu pada peraturan perundangan yang menempatkan BI sebagai otoritas pengawas bank. Bank Indonesia adalah lembaga yang diberi otoritas oleh pemerintah dalam pengawasan perbankan di Indonesia (termasuk perbankan syariah). Hal ini dijelaskan dalam Pasal 29 (1) (UU.No.7/1992 sebagaimana diubah dengan) UU No.10 Th.1998 tentang Perbankan yang berbunyi Pembinaan dan pengawasan bank dilakukan oleh Bank Indonesia. ${ }^{3}$ Adapun dalam Pasal 8 UU No.3/2004 tentang Perubahan atas UUNo.23 Th.1999 tentang Bank Indonesia dinyatakan bahwa Bank Indonesia mempunyai tiga tugas, yaitu a) menetapkan dan melaksanakan kebijakan moneter; b) mengatur dan menjaga kelancaran sistem pembayaran; dan c) mengatur dan mengawasi bank.

Pengaturan dan pengawasan bank syariah yang dilakukan oleh BI meliputi aspek produk dan transaksi.Hal tersebut terinci dalam PBI No. 7/35/PBI/2005 perubahan atas No. 6/24/PBI/2004 tentang Bank Umum Yang Melaksanakan Kegiatan Usaha Berdasarkan Prinsip Syariah.Setiap bank syariah pada dasarnya wajib menerapkan prinsip syariah dan prinsip kehati-hatian dalammelakukan kegiatan usahanya yang meliputi ${ }^{4}$ :

a. melakukan penghimpunan dana dari masyarakat dalam bentuk simpanan dan investasi, antara lain: (1) giro berdasarkan prinsip wadi'ah; (2) tabungan berdasarkan prinsip wadi'ah dan atau mudharabah; atau (3) deposito berjangka berdasarkan prinsip mudharabah

b. melakukan penyaluran dana melalui : (1) prinsip jual beli berdasarkan akad antara lain: murabahah, istishna, salam. (2) prinsip bagi hasil berdasarkan akad antara lain: mudharabah dan musyarakah. (3). prinsip sewa menyewa berdasarkan akad antara lain: ijarah dan ijarah muntahiya bittamlik. (4) prinsip pinjam meminjam berdasarkan akad qardh.

c. melakukan pemberian jasa pelayanan perbankan berdasarkan akad antara lain: (1) wakalah (2) hawalah (3) kafalah (4) rahn.

d. membeli, menjual dan/atau menjamin atas risiko sendiri surat berharga pihak ketiga yang diterbitkan atas dasar transaksi nyata (underlying transaction) berdasarkan prinsip syariah;

${ }^{3}$ Muhammad (2012). Hand Out Mata Kuliah Lembaga Perekonomian Islam. Yogyakarta: Magister Studi Islam, Program Pascasarjana, Fakultas Ilmu Agama Islam, Universitas Islam Indonesia.

${ }^{4}$ Peraturan Bank Indonesia No. 6/24/PBI/2004 tentang Bank Umum Yang Melaksanakan Kegiatan Usaha Berdasarkan Prinsip Syariah Bab V Kegiatan Usaha Pasal 36. 
e. membeli surat berharga berdasarkan prinsip Syariahyang diterbitkan oleh Pemerintah dan/atau Bank Indonesia, dll.

Mengingat beragamnya kegiatan bank syariah ditambah dengan kewajiban mentaati aturan syariah, maka proses pengawasan melalui lembaga independen menjadi urgen dilakukan. Dalam konteks Indonesia, tugas mengawasi aspek syariah dari operasional bank syariah ini menjadi kewenangan Dewan Syariah Nasional atau disingkat DSN. DSN adalah lembaga yang dibentuk oleh Majelis Ulama Indonesia (MUI) yang mempunyai fungsi melaksanakan tugas-tugas MUI dalam menangani masalah-masalah yang berhubungan dengan aktivitas lembaga keuangan Syariah. Salah satu tugas pokok DSN adalah mengkaji, menggali, dan merumuskan nilai dan prinsipprinsip hukum Islam (Syariah) dalam bentuk fatwa untuk dijadikan pedoman dalam kegiatan transaksi di lembaga keuangan syariah. ${ }^{5} \mathrm{DSN}$ merupakan satu-satunya badan yang mempunyai kewenangan mengeluarkan fatwa Syariahterhadap jenis-jenis kegiatan, produk, dan jasa keuangan syariah, serta mengawasi penerapan fatwa dimaksud oleh lembaga-lembaga keuangan di Indonesia.

Tugas utama Dewan SyariahNasional mengacu pada Keputusan DSN No. 01 tahun 2000 tentang Pedoman Dasar Dewan SyariahNasional MUI, antara lain meliputi: (1) menumbuhkembangkan penerapan nilai-nilai syariahdalam kegiatan perekonomian pada umumnya dan keuangan khususnya; (2) mengeluarkan fatwa atas jenis-jenis kegiatan usaha; (3) mengeluarkan fatwa atas produk dan jasa keuangan syariah; dan (4) mengawasi penerapan fatwa yang telah dikeluarkan. ${ }^{6}$

DSN memiliki sifat yang menyeluruh dalam artian pengawasan yang dilakukannya bersifat nasional. Sedangkan dalam prakteknya pengawasan yang bersifat lebih lokal pada bank syariahsecara langsung perlu dilakukan. Untuk mengawasi bank syariahsecara lebih langsung, maka kepanjangan tangan DSN berupa Dewan Pengawas Syariah(DPS) pun dibentuk. Pembentukan Dewan Pengawas Syariah antara lain didasari pada kesadaran akan pentingnya menjaga kegiatan usaha bank syariahagar senantiasa berjalan sesuai dengan nilai-nilai syariah.Selain itu, pengawasan yang lebih melekat dinilai perlu dilakukan sehingga kinerja bank syariahdapat terus dipantau agar sesuai dengan fatwa DSN. Dalam kerangka inilah, maka dibentuk Dewan Pengawas Syariahsesuai ketentuan penjelasan UU No.10 Tahun 1998 Pasal 6 huruf m.

Dalam ketentuan penjelasan tersebut diatur bahwa pokok-pokok ketentuan yang ditetapkan oleh Bank Indonesia terkait bank syariahantara lain memuat (a) kegiatan usaha dan produk-produk bank berdasarkan prinsip syariah; (b) pembentukan dan tugas Dewan Pengawas Syariah; dan (c) persyaratan bagi pembukaan kantor cabang yang melakukan kegiatan usaha secara konvensional untuk melakukan kegiatan usaha

${ }^{5}$ Rifqi Muhammad (2008). Akuntansi Keuangan Syari'ah. Yogyakarta: P3EI Press.

${ }^{6}$ Rasyid Rizani (2012), 'Penerapan Prinsip Syariah dalam Produk Perbankan Syariah' Artikel Direktorat Jenderal Badan Peradilan Agama, Mahkamah Agung RI, diakses dari http://www.badilag.net/data/ARTIKEL/Penerapan\%20prinsip\%20syariah\%20di\%20bank\%20syariah. pdf pada 15 Mei 2013. 
berdasarkan Prinsip Syariah. Dengan demikian, keberadaan Dewan Pengawas Syariahmendapatkan legalitas yang kuat dalam sistem perundangan di Indonesia.

Dewan Pengawas Syariahmelaksanakan tugasnya mengawasi bank syariahdengan sejumlah ketentuan, diantaranya wajib mengikuti fatwa dari DSN dan statusnya sebagai dewan yang ditempatkan di bank syariahyang keanggotaannya ditetapkan berdasarkan rekomendasi DSN yang bertugas mengawasi penerapan prinsip syariahdalam kegiatan usaha bank. Selain itu, keanggotaan Dewan Pengawas Syariahjuga harus mendapat persetujuan BI.

Adapun mengenai pedoman pengawasan maupun tatacara penyampaian laporan hasil pengawasan telah diatus dalam Surat Edaran No. 8/19/DPBS tanggal 24 Agustus 2006 Perihal Pedoman Pengawasan Syariah dan Tata Cara Pelaporan Hasil Pengawasan bagi DPS. Laporan hasil pengawasan Syariah beserta kertas kerja pengawasan yang telah disusun oleh DPS, sesuai dengan peraturan ini, disampaikan kepada Direksi, Komisaris, DSN, dan juga BI. Laporan hasil pengawasan Syariahitu sendiri, setidaknya harus memuat beberapa hal, yaitu: (1) hasil pengawasan atas kesesuaian kegiatan operasional bank terhadap fatwa yang dikeluarkan oleh DSN-MUI; (2) opini syariah ${ }^{7}$ atas pedoman operasional dan produk yang dikeluarkan oleh bank; (3) hasil kajian atas produk dan jasa baru yang belum ada fatwa untuk dimintakan fatwa kepada DSN-MUI; dan (4) opini syariahatas pelaksanaan operasional bank secara keseluruhan dalam laporan publikasi bank.

\section{KERANGKA AUDIT SYARIAH}

Landasan syariah dari pelaksanaan audit syariah antara lain dapat dirujuk pada penafsiran atas QS. Al Hujurat [49]: 6 yang terjemahan artinya adalah sebagai berikut: "Hai orang-orang yang beriman, jika datang kepadamu orang fasik membawa suatu berita, maka periksalah dengan teliti agar kamu tidak menimpakan suatu musibah kepada suatu kaum tanpa mengetahui keadaannya yang menyebabkan kamu menyesal atas perbuatanmu itu. " Ayat ini menunjukkan pentingnya pemeriksaan secara teliti atas sebuah informasi karena bisa menjadi penyebab terjadinya musibah atau bencana. Dalam konteks audit syariah, pemeriksaan laporan keuangan dan informasi keuangan lainnya juga menjadi sangat penting, mengingat keduanya dapat menjadi sumber malapetaka ekonomi berupa krisis dan sebagainya jika tidak dikelola secara maksimal.

Audit syariah dapat dimaknai sebagai suatu proses untuk memastikan bahwa aktivitas-aktivitas yang dilakukan oleh institusi keuangan Islam tidak melanggar syariah atau pengujian kepatuhan syariah secara menyeluruh terhadap aktivitas bank syariah.Tujuan audit syariah adalah untuk memastikan kesesuaian seluruh operasional

${ }^{7}$ Opini Syari'ah adalah pendapat kolektif dari DPS yang telah dibahas secara cermat dan mendalam mengenai kedudukan /ketentuan syari'ah yang berkaitan dengan produk atau aktivitas LKS. Opini Syari'ah dapat dijadikan pedoman sementara sebelum adanya fatwa DSN tentang masalah tertentu. 
Minarni: Konsep Pengawasan, Kerangka Audit Syariah...

bank dengan prinsip dan aturan syariah yang digunakan sebagai pedoman bagi manajemen dalam mengoperasikan bank syariah.

Hal-hal yang dilakukan pada audit bank syariah meliputi ${ }^{8}$ :

a. pengungkapan kewajaran penyajian laporan keuangan dan unsur kepatuhan syariah,

b. memeriksa akunting dalam aspek produk, baik sumber dana ataupun pembiayaan,

c. pemeriksaan distribusi profit

d. pengakuan pendapatan cash basis secara riil

e. pengakuan beban secara accrual basis

f. dalam hubungan dengan bank koresponden depositori, pengakuan pendapatan dengan bagi hasil.

g. pemeriksaan atas sumber dan penggunaan zakat

h. ada tidaknya transaksi yang mengandung unsur-unsur yang tidak sesuai dengan syariah

Hal-hal di atas adalah unsur-unsur yang harus ada dalam audit syariah, meskipun demikian prosedur audit yang telah ada tetap memiliki peran dalam audit pada perbankan syariah. Prosedur audit secara umum antara lain?:

a. prosedur analitis/mempelajari dan membandingkan data yang memiliki hubungan

b. menginspeksi/pemeriksaan dokumen,catatan dan pemeriksaan fisik atas sumber-sumber berwujud,

c. mengkonfirmasi/pengajuan pertanyaan pada pihak intern atau ekstern untuk mendapat informasi

d. menghitung dan menelusur dokumen

e. mencocokkan ke dokumen.

AAOIFI (Accounting and Auditing Organization for Islamic Financial Institutions) sebagaimana telah disebutkan sebelumnya mengeluarkan dan mensahkan standar audit yang berlaku pada lembaga keuangan syariah termasuk bank yang kemudian banyak diacu di berbagai negara. Standar Auditing AAOIFI untuk audit pada lembaga keuangan syariah sendiri mencakup lima standar, yaitu tujuan dan prinsip (objective and principles of auditing), laporan auditor (auditor's report), ketentuan keterlibatan audit (terms of audit engagement), lembaga pengawas syariah (shari'a supervisory board), tinjauan syariah (shari'a review). ${ }^{10}$ Adapun penjelasan singkat dari kelima standar tersebut adalah sebagai berikut:

${ }^{8}$ M. Syafi'i Antonio (2001). Bank Syari'ah Dari Teori Ke Praktek. Jakarta: Gena Insani Press bekerjasama dengan Tazkia Cendekia

${ }^{9}$ Al Haryono Jusup (2001). Auditing. Yogyakarta: STIE YKPN

${ }^{10}$ Rifaat Ahmed Abdel-Karim (1999), 'Accounting and Auditing Standards for Islamic Financial Institutions', Proceedings of the Second Harvard University Forum on Islamic Finance: Islamic Finance 
Pertama terkait tujuan dan prinsip. Tujuan dari sebuah audit laporan keuangan yaitu untuk memungkinkan auditor menyampaikan opini atas laporan keuangan tertentu dalam semua hal yang material dan sesuai dengan aturan dan prinsip Islam, AAOIFI, standar akuntansi nasional yang relevan, serta praktek di negeri yang mengoperasikan lembaga keuangan. Adapun prinsip etika profesi meliputi, kebenaran, integritas, dapat dipercaya, keadilan dan kewajaran, kejujuran, independen,objekivitas, kemampuan professional, bekerja hati-hati,menjaga kerahasiaan, perilaku professional dan menguasai standar teknis.

Kedua terkait laporan auditor. Elemen dasar dari laporan auditor (judul, alamat, paragraf pembukaan atau pengenalan, cakupan paragraf (gambaran dari audit), acuan ASIFI dan standar nasional yang relevan atau praktek, Uraian pekerjaan yang dilakukan auditor, Paragraf opini berisi sebuah ungkapan opini tentang laporan keuangan, Tanggal Laporan, Alamat Auditor dan Tanda Tangan Auditor). Terkait ruang lingkup paragraf,laporan auditor harus menggambarkan cakupan audit dengan menyatakan bahwa audit telah dilaksanakan sesuai ASIFI dan standar nasional yang relevan atau praktek telah sesuai dan tidak melanggar aturan dan prinsip Syariah. Ruang lingkup mengacu pada kemampuan auditor untuk melaksanakan prosedur audit yang dianggap penting dalam hal itu. Hal ini meyakinkan para pembaca bahwa audit telah berjalan sesuai ketetapan standar maupun praktek. Disamping itu juga telah sesuai dengan standar auditing nasional atau praktek mengikuti negara tempat auditor berada, hal ini terlihat dalam alamat auditor.Laporan itu termasuk sebuah pernyataan bahwa audit telah direncanakan dan dilaksanakan untuk memperoleh jaminan layak mengenai apakah laporan keuangan bebas dari pernyataan salah yang material.

Laporan auditor harus menggambarkan, antara lain:

a. pengujian, pada sebuah uji dasar, bukti yang mendukung sejumlah laporan keuangan dan pengungkapan.

b. menilai/menaksir prinsip akuntansi yang digunakan dalam persiapan laporan keuangan.

c. menilai perkiraan signifikan yang dibuat oleh manajemen dalam persiapan laporan keuangan.

d. mengevaluasi presentasi laporan keuangan secara keseluruhan.

Ketigaterkait ketentuan keterlibatan audit. Auditor dan klien harus menyetujui ketentuan perjanjian. Istilah setuju perlu disampaikan dalam surat penugasan audit sesuai kontrak. Isi dasar surat perjanjian adalah dokumen surat penunjukan dan menegaskan tanggung jawab auditor untuk klien dan bentuk setiap laporan yang akan diberikan oleh auditor.Keempat berkaitan dengan shari'a supervisory board yang intinya berisi penunjukan, komposisi dan laporan DPS.

into the 21 Century, (Cambridge, Massachusetts: Center for Middle Eastern Studies, Harvard University, 1999), pp.239-241. 
Minarni: Konsep Pengawasan, Kerangka Audit Syariah...

Kelima berkaitan dengan tijuanuan Syariah (shari'a review). Shari'ah review merupakan sebuah pengujian yang luas dari kepatuhan Syariah sebuah LKS, dalam seluruh kegiatannya. Pengujian ini meliputi penunjukan, persetujuan, kebijakan, produk, transaksi, memorandum (surat peringatan), dan anggaran dasar dari perserikatan, laporan keuangan, laporan (khususnya audit internal dan pengawasan bank central), sirkulasi,dll. Tujuan dari sebuah shari'a review adalah untuk memastikan bahwa seluruh aktivitas yang diselenggarakan dalam LKS tidak bertentangan dengan Syariah.DPS bertanggung jawab untuk membuat dan mengungkapkan sebuah opini dari suatu Lembaga Keuangan Syariah terhadap kepatuhannya pada Syariah.

Secara ringkas, audit Syariah terdiri dari tiga tahap, yaitu perencanaan, pengujian dan pelaporan. ${ }^{11}$ Dengan kerangka ini dan penjelasan di atas, maka nampak sejumlah perbedaan audit syariah dan audit konvensional, yaitu:

Tabel 1 Perbedaan antara Audit Syariah dan Audit Konvensional

\begin{tabular}{|c|c|c|}
\hline No & Audit Syariah & Audit Konvensional \\
\hline 1. & $\begin{array}{l}\text { Obyeknya LKS atau Lembaga } \\
\text { Keuangan Bank maupun Non Bank } \\
\text { yang beroperasi dengan prinsip } \\
\text { Syariah }\end{array}$ & $\begin{array}{l}\text { Obyeknya Lembaga Keuangan Bank } \\
\text { maupun Non Bank yang tidak beroperasi } \\
\text { berdasarkan prinsip Syariah }\end{array}$ \\
\hline 2. & Mengharuskan adanya peran DPS & $\begin{array}{l}\text { Tidak ada peran Dewan Pengawas Syariah } \\
\text { (DPS) }\end{array}$ \\
\hline 3. & $\begin{array}{l}\text { Audit dilakukan oleh Auditor } \\
\text { bersertifikasi SAS (Sertifikasi } \\
\text { AkuntansiSyariah) }\end{array}$ & $\begin{array}{l}\text { Audit dilakukan oleh Auditor Umum } \\
\text { tanpa ketentuan bersertifikasi SAS }\end{array}$ \\
\hline 4 & Standar Audit AAOIFI & Standar Auditing IAI \\
\hline 5 & $\begin{array}{l}\text { Opini berisi tentang Shari'a } \\
\text { Compliance atau tidaknya LKS }\end{array}$ & $\begin{array}{l}\text { Opini berisi tentang kewajaran atau } \\
\text { tidaknya atas penyajian } \\
\text { lap.Keuanganperusahaan }\end{array}$ \\
\hline
\end{tabular}

Dari paparan di atas dapat dipahami bahwa kerangka audit syariah antara lain memenuhi unsur sebagai berikut:

a. audit syariah dilakukan dengan tujuan untuk menguji kepatuhan perbankan syariah pada prinsip dan aturan syariah dalam produk dan kegiatan usahanya sehingga auditor syariah dapat memberikan opini yang jelas apakah bank syariah yang telah diaudit tersebut shari'ah compliance atau tidak.

b. audit syariah diselenggarakan dengan acuan standar audit yang telah ditetapkan oleh AAOIFI.

${ }^{11}$ Abdul Rahim Abdul Rahman (2008), 'Shari'ah Audit for Islamic Financial Services: The Needs and Challenges'Makalah dipresentasikan pada International Shari'ah Research Academy for Islamic Finance (ISRA) Islamic Finance Seminar, Kuala Lumpur, 11 November 2008. 
Minarni: Konsep Pengawasan, Kerangka Audit Syariah...

c. audit syariah dilakukan oleh auditor bersertifikasi SAS (Sertifikasi Akuntansi Syariah)

d. hasil dari audit syariah berpengaruh kuat terhadap keberlangsungan usaha perbankan Syariah dan kepercayaan seluruh pihak atas keberadaan LKS.

\section{TATA KELOLA PERUSAHAAN (CORPORATE GOVERNANCE)}

Corporate Governance adalah sistem hak, proses, dan kontrol secara keseluruhan yang ditetapkan secara internal dan eksternal atas manajemen sebuah entitas bisnis dengan tujuan untuk melindungi kepentingan-kepentingan semua stakeholder. ${ }^{12}$

Untuk memenuhi terlaksananya good corporate governance, diperlukan sebuah standar sebagai berikut:

1. Dewan Pengawas Syariah: Penunjukan, komposisi dan Laporan

2. Evaluasi terhadap Syariah.

3. Evaluasi internal terhadap Syariah..

4. Komite Audit dan Tata Kelola untuk LKS.

5. Independensi dari DPS.

6. Pernyataan atas Prinsip-prinsip tata kelola untuk LKS

7. Evaluasi Tanggung jawab social perusahaan

Sedangkan para pihak yang memegang peran kunci dalam corporate goverance LKS dapat dilihat pada bagan berikut ini ${ }^{13}$ :

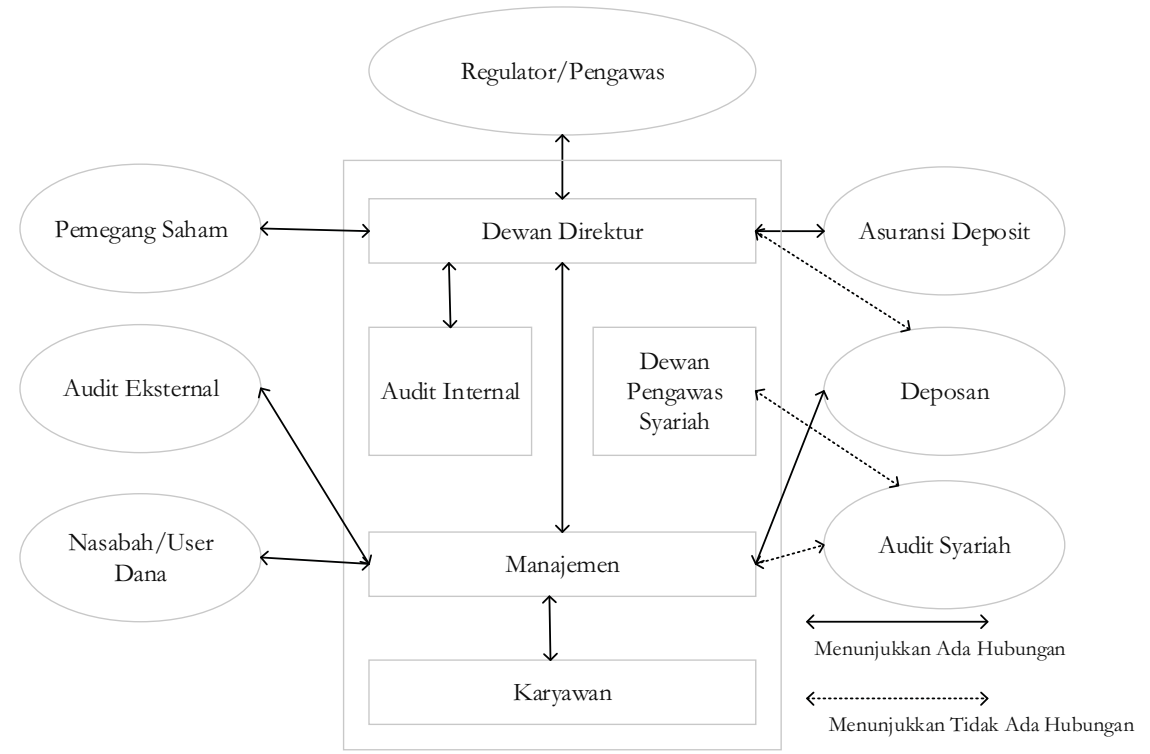

Bagan1 Pemegang Peran Kunci dalam Corporate Governance LKS

Selain standar dalam corporate governance LKS, diperlukan juga sebuah standar etis terhadap sumber daya insani yang meliputi kode etik bagi akuntan dan auditor pada

${ }^{12}$ Muhammad (2002),Manajemen Bank Syari'ah. Yogyakarta: AMP YKPN.

${ }^{13}$ M. Umer Chapra dan Habib Ahmed, terj. Ihwan A. Basri (2008). Corporate Governance Lembaga Keuangan Syari'ah. Jakarta: PT Bumi Aksara. 
LKS dan kode etik bagi karyawan LKS. Terdapat tiga bagian berkaitan dengan kode etik bagi akuntan dan auditor pada LKS, yaitu: (a) landasan syariah etika seorang akuntan (integritas, prinsip manusia sebagai khalifah di muka bumi, keikhlasan, kesalehan, kebenaran dan niat mengerjakan tugas dengan sempurna, takut pada Allah dalam segala hal, tanggung jawab manusia terlebih dahulu sebelum pada Allah); (b) prinsip-prinsip etika bagi akuntan (kepercayaan, legitimasi, obyektivitas, kompetensi profesi dan skill, perilaku berdasar keimanan, perilaku professional dan standar teknis); dan (c) aturan moral bagi akuntan.

Dari paparan di atas menjadi jelas bahwa Bank Indonesia (BI), Dewan Syariah Nasional (DSN) dan Dewan Pengawas Syariah (DPS) adalah pihak-pihak yang berperan dalam pengawasan Lembaga Keuangan Syariah (Bank Syariah). Dalam menjalankan fungsinya BI dan DSN lebih berperan dalam pengawasan, sedangkan DPS lebih berperan dalam pengendalianbank syariah.Kegiatan audit pada Bank Syariah terdiri dari tiga lapis, yaitu lapis pertama, audit internal yang dilakukan oleh auditor internal bank syariah yang bertugas dalam menguji (examination) kesesuaian laporan keuangan Bank Syariah yang sesuai dengan standar akuntansi yang berlaku dan tidak ada salah saji yang bersifat material, lapis kedua, Audit eksternal yang dilakukan oleh auditor dari luar bank syariah seperti BI atau akuntan publik yang tugasnya menguji kembali keakuratannya dari hasil audit internal, dan lapis ketiga, audit Syariah yang dilakukan oleh auditor bersertifikasi atau memiliki gelar Sertifikasi Akuntansi Syariah (SAS) yang bertugas untuk memastikan bahwa produk dan transaksi bank syariah telah sesuai dengan prinsip dan aturan syariah.

Dalam kerangka tata kelola perusahaan (corporate governance) audit eksternal berfungsi untuk memberikan opini pembanding atas audit internal dalam menjaga kepatuhan terhadap prinsip-prinsip standard akuntansi dan auditing, kesesuaiaan dengan prinsip syariah, dan lain-lain.Dalam prakteknya, audit eksternal dilakukan secara insidental (sewaktu-waktu), sedangkan audit internal dilakukan secara rutin karena fungsinya terkait dengan pengendalian di dalam perusahaan (Bank Syariah).Auditor eksternal berperan untuk memastikan bahwa laporan keuangan bank telah disajikan secara profesional dan sesuai dengan standar laporan keuangan dan memastikan bahwa keuntungan ataupun kerugian yang diungkapkan dalam laporan keuangan benar-benar merefleksikan kondisi bank sebenarnya serta memastikan bahwa profit yang dihasilkan bukan dari usaha yang bertentangan dengan Syariah. Auditor eksternal dalam hasil auditnya akan memberikan opini atau pendapat apakah hal-hal yang telah diaudit di Bank Syariah terutama laporan keuangannya telah disajikan secara wajar dan menggunakan prinsip dan standar akuntansi yang diterima umum. ${ }^{14}$

${ }^{14}$ Idealisme semacam ini kadang sulit diwujudkan dalam artian peraturan terkait audit syariah yang ada belum tentu dipatuhi di lapangan. Sebagai kasus perbandingan di Malaysia, lihat Nawal Binti Kasim, Shahul Hameed Mohamad Ibrahim \& Maliah Sulaiman (2009), 'Shariah Auditing in Islamic Financial Institutions: Exploring the Gap between the "Desired" and the "Actual", Global Economy \& Finance Journal, Vol. 2 No. 2 September 2009, pp. 127-137. 
Adapun auditor syariah akan menunjukkan hasil auditnya dengan memberikan opini apakah Bank Syariah yang diaudit dinyatakanshari'a complianceatau tidak.Apabila terjadi suatu kesalahan ataupun pelanggaran dalam kegiatan audit di Bank Syariah maka pihak yang harus bertanggung jawab adalah manajemen bank Syariah, sedangkan tanggung jawab auditor terletak pada opini yang diberikan.Kegiatan Pengawasan dan audit pada bank Syariah adalah satu rangkaian yang saling mendukung dalam kegiatan tata kelola perusahaan (corporate governance) yang harus dilakukan sesuai standar dan memperhatikan kode etik. Seluruh kegiatan ini dilakukan dengan tujuan utama yaitu menjaga kepercayaan masyarakat terhadap Lembaga Keuangan Syariah(Perbankan Syariah) dalam melaksanakan prinsip dan aturan Syariah pada produk dan operasional usahanya.

\section{PENUTUP}

Adanya pengawasan pada bank Syariah, audit Syariah dan corporate governance tidak berarti dapat menggantikan tugas manajemen bank dan tidak menjamin bank bebas dari krisis, kerugian maupun kebangkrutan. Hal tersebut disebabkan oleh beberapa faktor, antara lainhuman error, asymetric information, policydanregulationyang kurang mendukung, dan rewarddan punishment yang tidak jelas.

Untuk mewujudkan pengawasan yang efektif dan berdaya guna hendaknya Bank Indonesia sebagai pemegang otoritas pengawasan perbankan di Indonesia mendukung sepenuhnyaatas segala kegiatan pengawasan perbankan Syariahyang melibatkan DSN dan DPS dengan memberikan jaminan independen, insentif yang bernilai dan pertanggungjawaban yang jelas. Selain itu, Bank Indonesia bekerja sama dengan Kementrian Keuangan hendaknya membuat aturan dan kebijakan yang tegas mengenai reward dan punishmentpada manajemen bank Syariah atas komitmennya menjalankan usaha perbankan berdasarkan prinsip dan aturan Syariah.

Adapun untuk kegiatan audit Syariah hendaknya dijalankan sesuai mekanisme yang benar dan disesuaikan dengan standar audit AAOFI yang berlaku pada seluruh Lembaga Keuangan Syariah (LKS). Segala kelemahan yang ada dalam sistem audit, seperti faktor human error, asymmetric information, dan lainnyahendaklah diminimalkan untuk mencapai hasil yang tepat.Disamping itu, adanya tata kelola perusahaan (corporate governance) hendaklah dimaksimalkan agar dapat memenuhi tanggung jawab sosial perusahaan terhadap masyarakat dan seluruh pihak yang memiliki kepentingan dengan perusahaan.

\section{DAFTAR PUSTAKA}

Abdel-Karim, Rifaat Ahmed (1999). 'Accounting and Auditing Standards for Islamic Financial Institutions', Proceedings of the Second Harvard University Forum on Islamic Finance: Islamic Finance into the 21 Century, (Cambridge, Massachusetts: Center for Middle Eastern Studies, Harvard University, 1999), hal.239-241. 
Minarni: Konsep Pengawasan, Kerangka Audit Syariah...

(2001). 'International Accounting Harmonisation,

Banking Regulation, and Islamic Bank', The International Journal of Accounting, Volume 36, Issue 2, May 2001, hal. 169-193.

Antonio, M. Syafi'i (2001). Bank Syari'ah Dari Teori Ke Praktek. Jakarta: Gena Insani Press bekerjasama dengan Tazkia Cendekia.

Chapra, M. Umer dan Ahmed, Habib. terj. Ihwan A. Basri (2008). Corporate Governance Lembaga Keuangan Syari'ah. Jakarta: PT Bumi Aksara.

Jusup, Al Haryono (2001). Auditing. Yogyakarta: STIE YKPN

Kasim, Nawal Binti, Shahul Hameed Mohamad Ibrahim dan Maliah Sulaiman (2009), 'Shariah Auditing in Islamic Financial Institutions: Exploring the Gap between the "Desired" and the "Actual", Global Economy \& Finance Journal, Vol. 2 No. 2 September 2009, hal. 127-137.

Muhammad (2002), Manajemen Bank Syari'ah. Yogyakarta: AMP YKPN.

(2012).Hand Out Mata Kuliah Lembaga Perekonomian Islam. Yogyakarta: Magister Studi Islam, Program Pascasarjana, Fakultas Ilmu Agama Islam, Universitas Islam Indonesia.

Muhammad, Rifqi (2008). Akuntansi Keuangan Syari'ah. Yogyakarta: P3EI Press.

Peraturan Bank Indonesia No. 6/24/PBI/2004 tentang Bank Umum Yang Melaksanakan Kegiatan Usaha Berdasarkan Prinsip Syariah.

Rizani, Rasyid (2012). 'Penerapan Prinsip Syariah dalam Produk Perbankan Syariah' Artikel Direktorat Jenderal Badan Peradilan Agama, Mahkamah Agung RI, diakses dari http://www.badilag.net/data/ARTIKEL/Penerapan\%20prinsip\%20syariah\%20di \%20bank\%20syariah.pdfpada 15 Mei 2013.

Rahman, Abdul Rahim Abdul (2008). 'Shari'ah Audit for Islamic Financial Services: The Needs and Challenges' Makalah dipresentasikan pada International Shari'ah Research Academy for Islamic Finance (ISRA) Islamic Finance Seminar, Kuala Lumpur, 11 November 2008.

Undang-Undang Republik Indonesia Nomor 10 Tahun 1998 tentang Perubahan atas Undang-Undang Nomor 7 Tahun 1992 tentang Perbankan.

Undang-Undang Republik Indonesia Nomor 21 tahun 2011 tentang Otoritas Jasa Keuangan (OJK). 